\title{
Retraction Note to: Bacterial conversion of depolymerized Kraft lignin
}

\author{
Krithika Ravi ${ }^{1}$, Omar Y. Abdelaziz ${ }^{1}$, Matthias Nöbel ${ }^{1,3}$, Javier García-Hidalgo², Marie F. Gorwa-Grauslund², \\ Christian P. Hulteberg ${ }^{1}$ and Gunnar Lidén ${ }^{1 *}$ (D)
}

\section{Retraction to: Biotechnol Biofuels (2018) 11:240 https://doi.org/10.1186/s13068-018-1240-7}

The authors have retracted this article [1] because due to a mistake in the laboratory, SEC analyses of some of the lignin samples used had already been published as part of another article [2]. The data in the section "Characterization of depolymerized lignin streams" was therefore inaccurately presented as new, and part of the materials and methods section was incorrect. To avoid confusion this article has been retracted and the authors have been given the opportunity to resubmit their corrected data. All authors agree to this retraction.

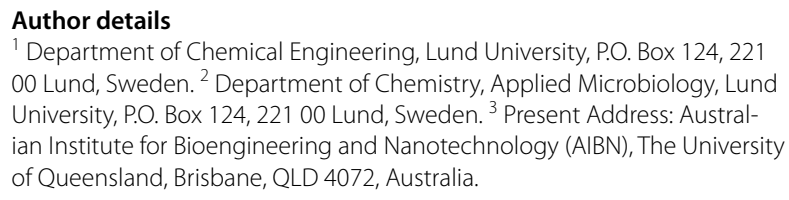

${ }^{1}$ Department of Chemical Engineering, Lund University, P.O. Box 124, 221 00 Lund, Sweden. ${ }^{2}$ Department of Chemistry, Applied Microbiology, Lund University, P.O. Box 124, 22100 Lund, Sweden. ${ }^{3}$ Present Address: Australian Institute for Bioengineering and Nanotechnology (AIBN), The University of Queensland, Brisbane, QLD 4072, Australia.

\author{
Publisher's Note \\ Springer Nature remains neutral with regard to jurisdictional claims in pub- \\ lished maps and institutional affiliations.
}

Received: 24 October 2018 Accepted: 24 October 2018

Published online: 12 November 2018

\section{References}

1. Ravi K, Abdelaziz OY, Nöbel M, García-Hidalgo J, Gorwa-Grauslund MF, Hulteberg CP, Lidén G. Bacterial conversion of depolymerized Kraft lignin. Biotechnol Biofuels. 2018;11:240. https://doi.org/10.1186/s1306 8-018-1240-7.

2. Abdelaziz OY, Li K, Tunå P, Hulteberg CP. Continuous catalytic depolymerisation and conversion of industrial kraft lignin into low-molecular-weight aromatics. Biomass Convers Biorefinery. 2018;8:455-70.

The original article can be found online at https://doi.org/10.1186/s1306 8-018-1240-7.

\footnotetext{
${ }^{*}$ Correspondence: gunnar.liden@chemeng.lth.se

${ }^{1}$ Department of Chemical Engineering, Lund University, P.O. Box 124, 221

00 Lund, Sweden

Full list of author information is available at the end of the article
}

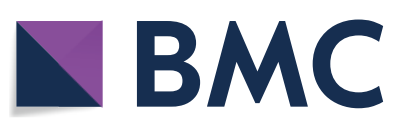

C The Author(s) 2018. This article is distributed under the terms of the Creative Commons Attribution 4.0 International License (http://creativecommons.org/licenses/by/4.0/), which permits unrestricted use, distribution, and reproduction in any medium, provided you give appropriate credit to the original author(s) and the source, provide a link to the Creative Commons license, and indicate if changes were made. The Creative Commons Public Domain Dedication waiver (http://creativecommons.org/ publicdomain/zero/1.0/) applies to the data made available in this article, unless otherwise stated. 